\title{
Pondok Pesantren Salaf in Java: Study of Santri Observation of Suhita's Heart
}

\author{
Agustin Lisnawati ${ }^{1, *}$, Wahidah Zumrotul Zuhro ${ }^{2}$ \\ ${ }^{1}$ Faculty of Da'wah Islamic Studies Guidance Study Program; ${ }^{2}$ Faculty of Tarbiyah and Teacher Training Study Program Tadris Ips IAIN Jember, \\ Jl. Mataram No.1, Karang Miuwo, Mangli, East Java, Jember 68136. \\ Email*: agustinajhaa234@gmail.com
}

\begin{abstract}
This article aims to reveal how the grammar or manners of a student towards Kiai and Bunyai. This article is expected to be able to be a view among the students and readers in the future regarding the moral values and rules not written in the boarding school Salaf but still implemented. The Islamic boarding school is known as a sacred place because it not only teaches academic and nonacademic knowledge, but also forms characters and students in accordance with the teachings of Islam. This research uses a type of qualitative descriptive research. The subject in this study was the novel Suhita by Khilma Anis. The way the data collection is done by the researchers by reading repeatedly and writing quotes that are found in novels into books. In this article there are two focus questions, first, how the communication between the nanny boarding school towards the students of the perspective of the novel Liver Suhita. Secondly, how is the moral value or rule described by the caliphate of the novel Suhita novels concerning the Pondok Pesantren Salaf. The results of this research show, firstly, the pattern of communication between the nanny Pondok Pesantren Salaf with a students of the study novel suhita. Secondly, the students ' obedience to the moral rules and values in Salaf pondok pesantren is a novel hati suhita.
\end{abstract}

Keywords: Students ' Obedience, Moral Values at Pondok Pesantren, Hati Suhita

\section{INTRODUCTION}

Pondok Pesantren is indeed inseparable from the lives of Indonesian people, because its existence has spread in various cities and remote villages. The existence of Islamic boarding school is one of the characteristics of the Unitary State of the Republic of Indonesia which is supported by the number of Muslims who occupy the majority position. So it is undeniable that Islamic boarding schools have a strong role and influence from various aspects of life, especially in the Muslim community itself, it can be a filter from the development or injection of ideas from outside.

One of the things that is applied as a filter in Islamic boarding schools is the observance of students or better known as the compliance of students that is common in Islamic boarding schools. Obedience in English obedience is defined as a form of disciplined individual or group behavior towards an order or regulation that has been agreed to by running it in a conscious state. Compliance is also considered as a form of positive behavior which can choose, do, obey, and respond. (Anita Dwi Rahmawati, 2015: 4-5)

From the observance of students in it there are moral values that are instilled down and down and become role models. this is a reference that distinguishes santri from non-santri, such as when a kiai or ibiliki runs in the boarding school environment, the santri stands, pausing his activities with his head bowed and his hands folded as a sign of respect. As for when a santri will walk in front of a Kiai or Ibiliki, then a santri will walk on his knees and bend his body, it can also be accompanied by shaking hands without looking or looking up towards the Kiai or Ibiliki as a form of santri devotion.

In the novel Hati Suhita Karya Khilma Anis has a uniqueness, which in his presentation there are still ancient stories that are associated with the events of the pesantren and strengthened by the use of Javanese language in several paragraphs in the novel. thus making this novel can be seen from various perspectives in accordance with the wishes of the author. In this case, researchers are interested in conducting research with a focus of research, first, how is the communication between caretakers of Islamic boarding schools to students in the novel Hati Hearts. Second, what are the moral values or rules described by Khilma Anis in the novel suhita about salaf Islamic boarding schools in Java.

\section{Anis Khilma Biography: History Study}

Khilma Anis was born in Jember on 4 October 1986. She began her writing skills in SUSANA (Suara Santri Assaidiyah) Tambakberas Jombang Magazine. He is also the editor in (MAN Jombang Student Magazine), and is the chief editor of KRESIBA Magazine (Creativity of Students of the Language Department) at the same school and boarding school.

In 2008, Khilma gave birth to a novel titled Be Purnamaku, ning, (JPN), published by the Matapena publisher in Yogyakarta. The Nobel Prize was favored by readers until it entered the third print. Together with his fellow writers, Matapena, he also compiled a Writing Guide titled Fiction Koran, which contains fiction writing guides for beginners. $\mathrm{He}$ is active in the 
Matapena community as a speaker and facilitator in every fiction and nonfiction writing training held at Islamic Boarding Schools and Schools in Java and Bali.

Khilma also wrote the novel Wigati; Lintang Manik Woro, a novel about keris, pesantren and the inner world of Javanese women. The novel was very popular with readers until the seventh edition was printed.

Khilma studied in the Department of Islamic Broadcasting Communication (KPI) of the Da'wah Faculty of UIN Sunan Kalijaga Yogyakarta. There, he was active in PMII and the ARENA Student Press Institute. In addition to being a campus journalist, she also gave birth to many short stories in ARENA Magazines and bulletins, including, Not a Prambayun Princess, Lembayung Senja, Because Longing Not Storytelling, Not Gendari, Wigati, Ilalang Men and Single Woman Luka. He also wrote short stories titled Under the Randu Tree (Sunday Morning), Gifts for Dawai (Sekar Magazine), Delima (Sekar Magazine), Dua Mutiara (Madinah Magazine) Surabaya, Wening (nu.or.id). He also wrote several independent film scripts, including, Annur in the Lenses (Jannur Film Community), the film Kinanti, (produced by the Kudus Arts Council). (Khilma Anis, 2019 hlm. 403-404)

The wife of Chazal Mazada also taught at Madradah Aliya Holy Muallimat. There, he guided KALAMUNA magazine, and became the activator of the Youth Scientific Work (KIR) community which led his students to win national scientific writing competitions. He invited 44 female writers to work until the birth of a short story book titled Second Friends, written by 44 female writers of their students and a graphic magazine called Nadira.

This work by Khilma Anis is closely related to the atmosphere of the pesantren because that is where he was born and grew. He took Mts at Pesantren Al Amien Sabrang Ambulu. During Aliyah, he was at the Pesantren Assaifiyyah Bahrul Ulum Tambakberas Jombang and at the Ali Maksum Islamic Boarding School Krapyak White House Yogyakarta during college. He became the granddaughter of Mbah KH. Turaichan Adjuri is a Holy Falak Expert. Then at this time Khilma and her family took care of the Annur Kesilir-Wuluhan Islamic Boarding School in Jember.

His love for the world of Puppet, Keris, fiber, babad and colossal stories made his writing unique to the inner world of Javanese women. Now, this mother of Nawaf Mazaya and Rasyiq Nibras manages the Annur Islamic Boarding School in Kesilir village, Wuluhan district, an area in South Jember. He also became the leader of Madrasah Aliyah in the same foundation. At present, the foundation established by his father, KH. Lukman Yasir, M.si., already has a complete education unit from Playgroup, Kindergarten, MI, Mts, and MA. Khilma became a teacher of sociology and Indonesian at Madrasah Aliyah Annur owned by her family.
In the midst of his busy teaching, writing, and caring for students, the puppeteer puppeteer $\mathrm{Ki}$ Timbul also runs a business. He is the owner of the Mazaya Shop, the owner of Mazaya Media publishing, as well as the official distributor of published works, the novel $\mathrm{Be}$ Purnamaku, Ning, Wigati, and the Hati Suhita Novel. (Khilma Anis, 2019 hlm. 404-405).

\section{METHOD: ANALYSIS}

The research of Hati Suhita's novel by Khilma Anis uses a descriptive qualitative approach, because the researcher will describe how the Santri obedience lives in the Pesantren towards Kiai and Biliki. Santri's obedience is reflected in the data in the form of word and sentence quotations, both in the form of dialogue, monologue, or narration contained in the novel Hati Suhita. The target in this study is the life and habits of students in Islamic boarding schools that tend to or generally have extraordinary obedience to the Kiai and Biliki. Primary data sources in this study are the novel Hati Suhita by Khilma Anis.

Data analysis was performed to obtain a description of observance in the life of the pesantren. The steps taken in data analysis are as follows: 1) identification of data in accordance with the formulation of the problem; 2) data are classified according to similar groups based on indicators of problems and research objectives; 3) data that is ready to be interpreted by giving meaning; 4) describe the results of the analysis; and 5) draw conclusions and test them. To facilitate researchers in conducting research, researchers make a division of labor in several stages, including the following: 1) selecting and stabilizing titles; 2) determine the formulation of the problem and the purpose of the problem; 3) repeatedly reading the novels being studied; 4) collect data in accordance with the aspects of the problem and provide a code; 5) selecting data by classifying data according to groups; 6) interpret data, which means giving meaning to the data that has been collected according to the data aspect in the description; 7) summarizing the results of data analysis; and 8) report in written form.

\section{Pesantren and Santri: Santri Compliance}

Within the scope of education in pesantren, obedience is in line with the understanding of Normasari (2013), where obedience is considered as someone's willingness to act on orders and wishes from the authority or teacher owner or Kiai. (Anita Dwi Rahmawati, 2015. Hlm. 4-5)

There are two factors that affect adherence to rules. First, internal factors include: self control, emotional conditions, and adjustment to school. Second, external factors which include: family, relationships with peers, school systems in the form of regulatory policies, school environment, demographics (age, ethnicity, gender), 
teacher figures, and penalties given by teachers (Brown, 2009; Sprague, Walker, Stieber, Simonsen and Nishioka, 2001; Stearns, 2014; Way, 2011). Obedient attitudes or behaviors towards rules are not only based on prevailing social norms, but encouragement in individuals in the form of self-control. Self Control (Self Control) is an effort or desire to foster self-order, obedience to the rules or rules that arise from an individual's internal awareness of his thoughts and feelings (Widodo, 2010). Psychological conditions of students such as boredom, laziness, fatigue, bad mood, lack of time management, impingement, sense of responsibility, self-awareness and self-control. (Anita Dwi Rahmawati, 2015. Hlm. 4-5)

Compliance of a santri to Kiai, can be classified in 3 parts, including: 1) prismatic observance shown by santri alumni; 2) apparent obedience; both of these behaviors are shown by active students who have a teacher and student bond with the kiai; and 3) absolute obedience. This absolute obedience is interpreted as an obedience that can not be interrupted, valid for life for a student or santri. Feelings of respect and obedience absolutely must be shown by students in all aspects of their lives. Forgetting the bond with the teacher is an ugliness and will eliminate the teacher's barakah and in the end the knowledge possessed by a student is useless. This is done not as a manifestation of total surrender to teachers who are considered to have authority, but because of the students' belief in the teacher's position as a channel of God's mercy bestowed on their students, both in this world and the hereafter. The unique patterns of relationship between Kiai and santri are influenced by the education literature that is used as a reference in Islamic boarding schools, one of which is the book of Taklim al Mutakalim (Dhofier, 1985: 55). (Eko Setiawan, 139).

\section{Pesantren and Santri: Moral Values in Pondan Pesantren}

The word moral comes from the word mos which means habit. Moral is about the good and bad teachings that are generally accepted about the changing attitude, obligations and others. Moral etymologically means: a) the overall rules of decency and habits that apply to certain groups, b) The teachings of decency, in other words about the principles and rules of decency which are learned systematically in ethics. In Greek it is called "ethos" to be a term that means norms, rules relating to good and bad issues in relation to human actions themselves, elements of personality and motives, human intentions and character. then "ethics" which means morality which reflects how the actual act of life in society, what is good and bad. Moral terminology is interpreted by various figures and schools who have different points of view: According to Franz Magnis, Suseno moral is the attitude of the heart that is revealed in outward acts (bearing in mind that action is a full expression of the heart), moral exists when people take good attitudes because he is aware of his obligations and responsibilities and is not looking for profit. Moral as a truly good attitude and deeds without strings attached.( Mohammad Yusuf. 2016. Hlm. 29-30)

Moral norms that are related to human behavior that can be measured in terms of good and bad. Polite or impolite, immoral or immoral. In this capacity the values of Pancasila have been translated into norms or norms of morality so that Pancasila is an ethical system in society, nation and state. There are two ways to instill moral values to students, including: internalization of the values of the "Yellow Book" and the use of religious activities in pesantren such as Tafaqquh Fiddin, rote learning, special prayer, prayer, empowerment of students, community development, Kiai prayer. There are also Islamic boarding schools that teach the study of aqeedah and morals, teach ta'dhim culture to the KiaiBiliki and people in the boarding school environment, teach responsibility, teach independently, teach students to be patient, education is done in full time, teach social interaction, ban for students to bring electronic equipment, Kiai-Biliki prayers and all the clerics and clerics accompanying the students. (Pelangi Blog, Peran Pondok Pesantren dalam Mendidik Akhlak dan Moral. 25 April 2017)

\section{Research Results and Discussion: Message and Heart of Sahita}

Pesantren in the Large Dictionary of Inodesia is defined as a boarding house where students live or where students learn to read the Koran and so on; cottage. According to the writer team of the Department of Religion (2003: 3) in the Pesantren learning pattern book defines that Islamic boarding school is Islamic education and teaching wherein there is interaction between KiaiBiliki and Ustad-ustadzah as teachers and students as students by taking place in the mosque or in the pages of the dormitory (pondok) to study and discuss religious text books by past ulama. Thus, the most important element for pesantren is the presence of Kiai-Biliki, students, mosques, dwellings (huts) and books (yellow books).

The legal basis for the existence of pesantren is in LAW OF THE REPUBLIC OF INDONESIA NUMBER 20 OF 2003 CONCERNING NATIONAL EDUCATION SYSTEM ARTICLE 1 which reads "Education is a conscious and planned effort to create an atmosphere of learning and learning process so that students actively develop their potential to have a spiritual spiritual power, self-control, personality, intelligence, noble character, and the skills needed by himself, society, nation and state."

Just like in Islamic boarding schools generally where a santri will remit memorization to the Kiai-Biliki and clerics in the cottage, in the heart of the heart is also found, namely.

Ummik left us and said good-bye about to listen to your sister-in-law. I kept my head down hiding sadly. (hal. 18) 
Every time, I deposit my memorization with the ummik (Has-in-laws from Suhita). Whenever I see Abah having free time, I always ask a lot of things about various sciences. All that was said was recorded in a book. I did it because my father told me their knowledge must be nitis to me, who is now his son.

practically never went anywhere. Just like a santri who lives in school again. I only leave if Ummik invites me. Or Ummik told me. And only went twice with Aruna. I've never even been home at all. (hal 262)

In a boarding school environment it becomes one of the obligations for a santri to be obedient to Kiai-Biliki and the rules of the pondok, not apart from the santri (absolute obedience), but compliance is also intended for alumni of boarding schools if they enter a pesantren called prismatic observance.

Since childhood, my father and mother had indoctrinated me that everything, my goals, my life goals, was dedicated to the Al-Anwar boarding school, my in-laws boarding school..

So, I can't have any other goals besides trying hard to become worthy to lead there. I was hospitalized in the Tahfid boarding school since I was young. It was Kiai and Mrs. Nyai Hannan who proposed that I should study in the hadith interpretation department even though I really wanted to study in the literature department. My mother's father agreed that as long as they wanted.

In fact, when I was in my seventh semester, kiai Hannan asked me to move my pesantren and leave my college so that I could be more rote in my new pesantren. I obey because it's their will. For the sake of their pesantren. (hal. 3)

A santri's obedience continues to be obedient to her husband as in the novels of the heart of Suhita is also described in a conversation and story so that it becomes interesting and adds insight to the reader. In a narration from Abu Hurairah radhiyallahu 'anhu, Rasulullah sallallaahu' alaihi wa sallam said: "If a woman has prayed five times a day, performed fasting in her month, kept her honor, and obeyed her husband, then she will enter heaven from any door she is will." (HR Ibnu Hibban dalam Shahihnya nomor 4163)

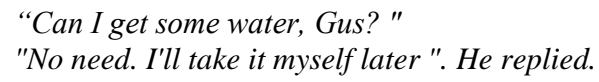

Sometimes, seeing his attitude towards me, I feel like Ekalaya, who bears the pain of being ignored and rejected by Drona's teacher. Ekalaya alias Palgunadi wants to master the science of Danuweda, the science of archery that only Drona Receipts have. But the rishi refused it raw because he had sworn an oath, Danuweda's knowledge would only be passed on to Arjuna, who was a descendant of Hastina. For him, Arjun was the one who would be the best at archery in the entire universe.

Drona's rejection, made Ekalaya learn on her own. Because of his love for Drona receipts, he made sculptures of Drona receipts and learned very seriously. Every time it starts, he will ask for the statue's blessing. While imagining, the statue is the true Drona receipt. So, he self-taught, he learned archery, if kridhaning Jemparing until the equivalent of his knowledge with Arjuna.

When Ekalaya's skill accidentally reaches the ears of other Drona students, Drona, along with Arjuna who is restless for fear of competition, immediately goes to Ekalaya.

Drona asks for dhaksina, or we are familiar with the teacher's request to students as a token of gratitude. Do you know what the Drona receipt asked for? He asked for the Ampal mustika ring, which was fused with Ekalaya's right thumb.

Ekalaya cut his thumb openly because of the teacher's request, at that time, he did not realize that with the cutting of his thumb, archery was destroyed because the thumb is the main tool. (hal. 11-12)

Like a santri where Kiai-Biliki says good words it becomes an obligation for his students to follow and carry out these words, because in the Islamic boarding school there is a stigma of blessing when obedience to Kiai-Biliki is done sincerely.

\footnotetext{
"Lin, do you need a honeymoon?" Ummik surprised me again. I'm shocked. How could Ummik talk like that? "Mboten ah, Mik."

"Anak-anake kancaku gitu. Gak papa lin. Birru juga ben leren sok pekerjaanne. Kamu juga biar istirahat dari mulang ngaji. Ummik sama abah mbok tinggal tiga harian gak masalah, lho." The center of my body warms up. I remember Mas Birru who I wanted so much. I want my passion and submissiveness to him who is perfect. "Mboten usah, Mik."

"Ah, gak popo. Jajal ya, besok nek Birru datang, Ummik bilang."

"Inggih, Mi. Kulo nderek." (hal. 124)
}

\section{CONCLUSIONS}

From the observance of students in it there are moral values that are instilled down and down and become role models. this is a reference that distinguishes santri from non-santri, such as when a kiai or ibiliki runs in the boarding school environment, the santri stands, pausing his activities with his head bowed and his hands folded as a sign of respect. As for when a santri will walk in front of a Kiai or Ibiliki, then a santri will walk on his knees and bend his body, it can also be accompanied by shaking hands without looking or looking up towards the Kiai or Ibiliki as a form of santri devotion.

\section{REFERENCES}

Anis Khilma. 2019. Hati Suhita. Yogyakarta: Telaga Aksara, 2019. 
Atsari Bambang Abu Ubaidillah Al, 8 Alasan Istri Taat Kepada Suami (13-01-2016) https://abuubaidillah.com/8alasan-istri-taat-kepada-suami

Anita Dwi Rahmawati.2015. Kepatuhan Santri Terhadap Aturan di Pondok Pesantren Modern. Surakarta : Program Magister Psikologi Sekolah Pascasarjana Universitas Muhammadiyah Surakarta, 4-5.

Blog Pelangi, Peran Pondok Pesantren Dalam Mendidik Akhlak Dan Moral (25 April 2017). https://www.pelangiblog.com/2017/04/peran-pondokpesantren-dalam-mendidik.html

Eko Setiawan, Eksistensi Budaya Patron Klien Dalam Pesantren: Studi Hubungan Antara Kiai Dan Santri (Malang: Fakultas Pertanian Universitas Brawijaya Malang Jl. Veteran), 139

https://www.google.com/url?sa=t\&rct=j\&q=\&esrc=s\&source=we b\&cd=1\&ved=2ahUKEwjanKv47P_kAhUOb30KHXVABzs QFjAAegQIABAC\&url=http\%3A\%2F\%2Flib.unnes.ac.id\%2 F27436\%2F1\%2F3301410034.pdf\&usg=AOvVaw31u87qm8MRTwfgrkmZpUh

http://pendis.kemenag.go.id/file/dokumen/uuno20th2003ttgsisdikn as.pdf

Kamus Besar Bahasa Indonesia

$(\mathrm{KBBI})$ https://kbbi.web.id/pesantren

Khilma Anis. 2019. Hati Suhita. (Yogyakarta: Telaga Aksara. Hlm. 403-404

Khilma Anis. 2019. Hati Suhita. (Yogyakarta: Telaga Aksara. Hlm. 404-405

Mohammad Yusuf, Pembinaan Moral Santri Di Pondok Pesantren Roudlotul Mubtadiin Desa Gemiring Lor Kecamatan Nalumsari Kabupaten Jepara (Semarang: Jurusan Politik Dan Kewarganegaraan Fakultas Ilmu Sosial Universitas Negeri Semarang, 2016), 29-30. https://www.google.com/url?sa=t\&rct=j\&q=\&esrc=s\&source $=$ web\&cd=1\&ved=2ahUKEwjanKv47P_kAhUOb30KHXVA
BzsQFjAAegQIABAC\&url=http\%3A\%2F\%2Flib.unnes.ac.id $\% 2$ F27436\%2F1\%2F3301410034.pdf\&usg=AOvVaw31u87qm8MRTwfgrkmZpUh

Pelangi Blog, Peran Pondok Pesantren Dalam Mendidik Akhlak Dan Moral (25 April 2017). https://www.pelangiblog.com/2017/04/peran-pondokpesantren-dalam-mendidik.html

Pengertian Pondok Pesantren Menurut Para Ahli https://penjelasan-menurut.blogspot.com/2017/08/pengertianpondok-pesantren-menurut.html

Rahmawati Anita Dwi. 2015. Kepatuhan Santri Terhadap Aturan Di Pondok Pesantren Modern. Surakarta: Program Magister Psikologi Sekolah Pascasarjana Universitas Muhammadiyah Surakarta.

Setiawan Eko. Eksistensi Budaya Patron Klien Dalam Pesantren: Studi Hubungan Antara Kiai Dan Santri. Malang: Fakultas Pertanian Universitas Brawijaya Malang Jl. Veteran.

Shofiyuddin Ahmad. Studi Model Pendidikan Moral Di Pesantren Darut Tauhid Al-Alawi Tuban Dalam Mencegah Kenakalan Santri. Gresik : Dosen Pendidikan Agama Islam Universitas Muhammadiyah Gresik. http://digilib.umg.ac.id/files/disk1/20/jipptumg--ahmadshofi1988-1-shofi.pdf

Syarif Zainuddi. Mitos Nilai-Nilai Kepatuhan Santri. Pamekasan : Sekolah Tinggi Ilmu Tarbiyah Al-Khairat Pamekasan. https://www.google.com/url?sa=t\&rct=j\&q=\&esrc=s\&source $=$ web $\& c d=8 \&$ cad $=$ rja $\& u a c t=8 \&$ ved $=2$ ahUKEwjsqMbj6f_kA hWkmuYKHcveA_0QFjAHegQICBAC\&url=http $\% 3 \mathrm{~A} \% 2 \mathrm{~F} \%$ 2Fejournal.stainpamekasan.ac.id\%2Findex.php $\% 2$ Ftadris $\% 2 \mathrm{~F}$ article\%2FviewFile\%2F376\%2F365\&usg=AOvVaw1cgMHu vd-zxjXL50F0MLnL

Undang-Undang Republik Indonesia Nomor 20 Tahun 2003 Tentang Sistem Pendidikan Nasional 
THIS PAGE INTENTIONALLY LEFT BLANK 